\section{Mass extinctions}

\section{Catastrophic vegetation changes}

\author{
Margaret E. Collinson
}

DiNOSAURS and ammonites are probably the best-known examples of the many species that became extinct at the Cretaceous-Tertiary $(\mathrm{K}-\mathrm{T})$ boundary ${ }^{1,2}$. Because there are unusually high concentrations of iridium in the clays at the boundary, it is possible that the biotic changes were caused by asteroid impact ${ }^{3,4}$. Terrestrial phenomena such as vulcanism may, however, have been responsible for the extinctions ${ }^{5-7}$. Although ecological disruptions of marine biota at this time are widely documented ${ }^{1-6}$, little is known about the influence of the $\mathrm{K}-\mathrm{T}$ event on terrestrial species ${ }^{8}$. New evidence from fossil land plants (refs 9, 10 and page 148 of this issue ${ }^{11}$ ) reveals a widespread ecological trauma, coupled with floral turnover, which occurred at the same time as the marine disruptions.

Late Cretaceous floras were dominated by flowering plants in at least four distinctive floral provinces ${ }^{12,13}$. In the Northern Hemisphere the Aquillapollenites province includes eastern Siberia and western North America, and the Normapolles province included Europe and eastern North America. In the pollen and spore record several features characterize the $\mathrm{K}-\mathrm{T}$ event. There was a major floral turnover in the Aquillapollenites province, with extinction of many forms; more restricted turnover in the Normapolles province; but little or no turnover in Southern Hemisphere provinces. A marked increase in the development of modern pollen types occurred in the early Tertiary ${ }^{8,12,13}$.

The first detailed evidence of the vegetational expression of these floral changes, the 'fern spike', was found during a study of the $\mathrm{K}-\mathrm{T}$ boundary in the Raton Basin of the western interior of North America ${ }^{14}$. Destruction of preboundary angiosperm-dominated vegetation was followed by establishment of a fern-dominated, coal-forming mire vegetation. Many Cretaceous flowering plants became extinct, although some persisted across the boundary. Re-establishment of angiosperm dominance followed "within a few centimetres of the boundary" ${ }^{14}$ but with very different floral composition.

These events are known to have occurred throughout the western interior of North America and in Canada9. Floral change in angiosperm groups falls into three categories: major extinctions but with some species persisting across the boundary; groups showing evolutionary changes between pre- and post-boundary forms; and groups largely unaffected at the boundary. In the first group, different species become extinct in the northern and southern parts of the region, and macrofloral analysis ${ }^{11}$ reveals differential extinction in the southern (up to 75 per cent of Cretaceous species) compared with the northern (up to 25 per cent) part of the western interior. The presence of a post-boundary, fern-dominated, coalforming, mire vegetation was confirmed by the macrofossil analyses.

A recent palynological study ${ }^{10}$ from a marine sequence in Japan reveals a fern spike at the same time as the major faunal turnover in marine biota. This study not only extends the geographical range over which the ecological disruption in the Aquillapollenites province has been recognized, but demonstrates, for the first time, that the marine and terrestrial events happened at the same time.

A relationship between leaf form and prevailing conditions has been observed, where vegetation is in equilibrium with climate. Using this relationship, Wolfe and Upchurch ${ }^{11}$ report in this issue additional aspects of the $\mathrm{K}-\mathrm{T}$ boundary events in western North America. These include an increase in precipitation across the boundary with the initiation of rain forest environments in the early Tertiary; little overall change between late Cretaceous and early Tertiary temperatures; and a high survival rate of deciduous versus evergreen taxa across the boundary both in northern conifer-dominated and in southern angiosperm-dominated vegetation. An increase in coniferous elements in the post-boundary vegetation occurred in the Montana/Wyoming area of the western interior of North America ${ }^{11}$ and also in $\mathrm{Japan}^{10}$. (It may also occur in the western Mediterranean if magnetostratigraphic correlation of the sections studied proves correct ${ }^{15}$.)

Vegetational changes across the boundary have been compared with the destruction and renewal of modern vegetation after catastrophic volcanic eruption ${ }^{14,16,17}$. Replacement climax vegetation may, in such cases, be controlled by the disruptive effects of continued disturbance, without reaching equilibrium with the prevailing climate $^{18}$. Thus, palaeoclimatic inferences based on $\mathrm{K}-\mathrm{T}$ boundary vegetation sequences assume that no subsequent disturbance affected post-boundary vegetation succession. Sedimentological or other evidence is needed to confirm this assumption

To explain the differential extinction of evergreen taxa, Wolfe and Upchurch ${ }^{11}$ suggest a $1-2$ month low (near $0^{\circ} \mathrm{C}$ ) temperature change at or near the boundary. The magnitude and duration of such an excursion is clearly constrained by the high survival rate of large aquatic ectotherms ${ }^{11}$. But it seems possible that seeds of evergreen taxa survived in the seed bank and re-established when conditions became less hostile.

Despite possible problems with such details, it seems clear that the vegetation did change across the $\mathrm{K}-\mathrm{T}$ boundary in the Aquillapollenites province ${ }^{9-11}$. Angiosperm-dominated forests were destroyed and a fern-dominated, coalforming mire vegetation became established immediately post-boundary at the same time as marine biotic changes. Turnover in angiosperm floras varied according to taxon and geographical area, but included both major extinctions and persistence more or less unchanged across the boundary. Post-boundary vegetation was therefore different in many ways from that pre-boundary. In some areas conifers increased in abundance and selection for deciduousness had a profound effect on Northern Hemisphere but not Southern Hemisphere vegetation ${ }^{11}$.

If volcanism in the Indian Deccan Traps did cause the extinctions, as has recently been suggested ${ }^{19}$, it is indeed surprising that the Southern Hemisphere provinces show no evidence of the ecological trauma of the Aquillapollenites province. Detailed examination of $\mathrm{K}-\mathrm{T}$ boundary sections from these provinces is clearly needed. The last appearance of the dinosaurs may well have preceded these vegetational changes ${ }^{8}$, but of the many possible reasons for the extinction of the dinosaurs, those involving a short cold period or enforced changes in herbivore diet bear reinvestigation.

1. Raup, D.M. \& Sepkoski, J.J. Science 231, 833-836 (1986)

2. Raup, D.M. Science 231, 1528-1533 (1986).

3. Alvarez, L.W., Alvarez, W., Asaro, F. \& Michel. H.V Science 208, 1095-1098 (1980)

4. Hsu, K.J. et al. Science 216, 249-256 (1982)

5. Officer, C.B. \& Drake, C.L. Science 219, 1383-1390 (1983).

6. Officer, C.B. \& Drake, C.L. Science 227, 1161-1167 (1985)

Wolbach, W.S., Lewis, R.S. \& Anders, E. Science 230 $167-170$ (1985)

8. Hickey, L.J. Nature 292, 529-531 (1981).

9. Tschudy, R.H. \& Tschudy, B.D. Geology 14, 667-670 (1986).

10. Saito, T., Yamanoi, T. \& Kaicho, K. Nature 323, 253-256 (1986)

1. Wolfe, J.A. \& Upchurch, G.R. Nature 324, 148-152 (1986)

12. Batten, D.J. in Fossils \& Climate (ed. Brenchley, P.) 127 164 (Wiley, Chichester, 1984).

13. Muller, J. Ann. Mo. bot. Gdn. 71, 419-443 (1985).

14. Tschudy, R.H., Pilmore, C.L., Orth, C.J., Gilmore, J.S \& Knight, J.D. Science 225, 1030-1032 (1984)

15. Ashrof, A.R. \& Erben, H.K. Palaeontographica 200, 111$163(1986)$

16. Leahy, G.D., Spoon, M.D. \& Retallack, G.J. Nature 318 318 (1985).

. Spicer, R.A., Burnham, R.J., Grant, P.G. \& Glicken, H Fern. J. 75, 1-5 (1985).

18. Cross, A.T.\& Taggart, R.E. Ann. Mo. bot. Gdn. 69, 676 734 (1980).

19. Courtillot, V., Besse, J., Vandamme, D., Jaeger, J.-J. \& Montigny, R. C. r. hebd. Seanc. Acad. Sci. Paris. Ser II 303, 863-868 (1986).

Margaret E. Collinson is in the Department of Biology, King's College London (KQC), Kensington Campus, Campden Hill Road, London W8 $7 A H$, UK 